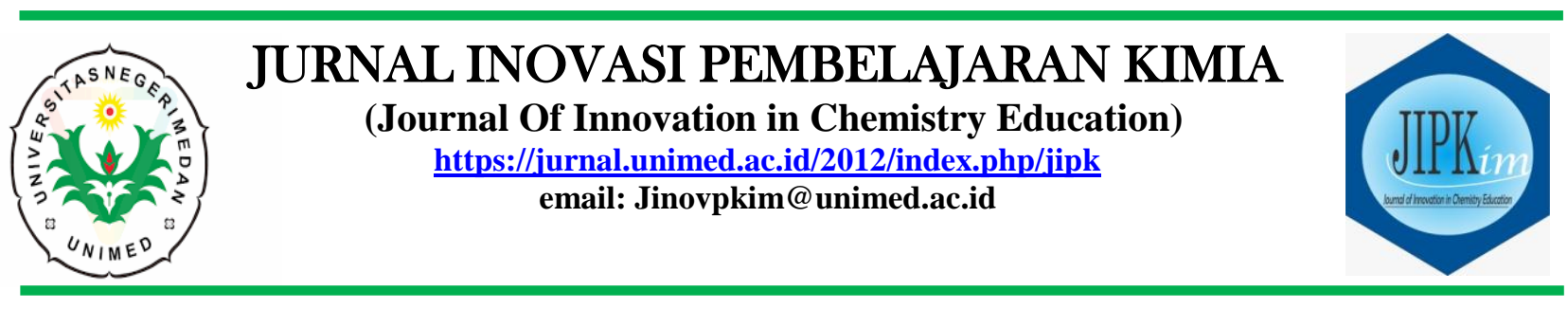

$\begin{array}{ll}\text { Masuk } & : \text { 1 Agustus 2020 } \\ \text { Revisi } & : \text { 8 September 2020 } \\ \text { Diterima } & : \text { 15 September 2020 } \\ \text { Diterbitkan } & : \text { 30 Oktober 2020 } \\ \text { Halaman } & : 58-63\end{array}$

\title{
Analisis Problem Based Learning Dan Discovery Learning Menggunakan Macromedia Flash Pada Materi Termokimia
}

\author{
Freddy Tua Musa Panggabean ${ }^{1 *}$, Muhammad Fadli Harahap ${ }^{1}$ \\ ${ }^{1}$ Program Studi Pendidikan Kimia, Universitas Negeri Medan, Medan \\ *Alamat Korespondensi: freddypanggabean@unimed.ac.id
}

\begin{abstract}
This study aims: (1) to find out wheter the average value of student learning outcomes taught by $P B L$ and DL models is greater than the KKM value (2) to find out whether there is class interaction and motivation on the value of student learning outcomes. This research is type of One-Group pretestposttest Design research. The analysis technique used is: (1) One sample t-test; (2) Two Way Anava. From the analysis of the learning outcomes data obtained (1) differences in student learning outcomes $(80.47 \pm 8.3336)$ taught by applying PBL models using macromedia flash and student learning outcomes (78.269 \pm 9.994$)$ are taught by applying the DL model using macromedia flash where a $t$ test of 1.684 is obtained; (2) There a $F_{\text {hit }}$ price of $6.235>F_{\text {table }} 4.00$ and a sig value of $0.015<0.05$ meant that the factor $A$ was real; inter-row results $(B)$ have a $F_{\text {hit }}$ price of $0.025<F_{\text {table }} 4.00$ and a sig value of $0.975>0.05$ means that the factor $B$ is not real; interaction results $(A B)$ has a $F_{\text {hit }}$ price of $3.860>F_{\text {table }} 3.45$ and a sig value of $0.027<0.05$ means that the factor $A B$ is real.
\end{abstract}

Keywords: Problem Based Learning, Discovery Learning, Macromedia Flash

\section{PENDAHULUAN}

Proses pembelajaran kimia menekankan pada pemberian pengalaman melalui penggunaan keterampilan proses dan sikap ilmiah. Kurikulum 2013 mengamanatkan prinsip pembelajaran yang berpusat pada peserta didik, mengembangkan kreativitas, menciptakan kondisi menyenangkan dan menantang, bermuatan nilai, etika, estetika, logika, dan kinestetika, serta menyediakan pengalaman belajar yang beragam melalui penerapan berbagai strategi dan metode pembelajaran yang kontekstual, efektif, efisien, dan bermakna
(Permendikbud, 2014). Bahan ajar adalah salah satu komponen untuk meningkatkan keterampilan siswa, tetapi bahan ajar yang ada saat ini, terutama tentang bahan termokimia belum memiliki konten maksimum. Selain itu, aspeknya adalah pengetahuan tentang bahan termokimia yang merupakan aspek sains sebagai batang tubuh, termokimia dalam konteks yang merupakan aspek sains sebagai proses penyelidikan, tingginya tingkat keterampilan berpikir yang merupakan ilmu sebagai cara berpikir, dan sikap yang merupakan aspek interaksi antara sains, teknologi, dan masyarakat (Sutiani et al., 2020). 
Penggunaan metode ceramah kurang efektif, karena siswa hanya mendengarkan guru yang sedang menjelaskan pelajaran, sehingga siswa kurang aktif dan merasa bosan dalam proses pembelajaran. Meskipun guru memberikan sesi pertanyaan bagi siswa, tetapi hanya siswa aktif saja yang memanfaatkan kesempatan bertanya, sedangkan siswa yang kurang aktif lebih memilih diam saja atau bicara dengan siswa lain.

Berdasarkan uraian masalah di atas peneliti melihat pentingnya model pembelajaran yang inovatif dan penggunaan media yang efektif untuk meningkatkan kompetensi siswa. Model pembelajaran yang inovatif seperti Problem Based Learning (PBL) dan Discovery Learning (DL) serta penggunaan macromedia flash diharapkan dapat menjawab permasalahan di atas untuk membantu siswa serta meningkatkan motivasi maupun hasil belajar siswa.

\section{KAJIAN LITERATUR}

\section{Problem Based Learning}

Penerapan model Problem Based Learning dapat mempengaruhi hasil belajar siswa sebesar $9,35 \%$ dimana harga $t_{\text {hitung }}=2,55$ lebih besar dari harga $t_{\text {tabel }}=2,00$ pada taraf signifikan 5\% (Desriyanti \& Lazulva, 2016). Selain itu, penerapan model Problem Based Learning juga dapat meningkatkan prestasi belajar siswa berdasarkan aspek kognitif dimana pada siklus I sebesar 54,05\% dan meningkat pada siklus II sebesar 78,38\% (Nuryanto et al., 2015). Terdapat perbedaan yang signifikan hasil belajar siswa yang diajar menggunakan model pembelajaran Problem Based Learning berorientasi kolaboratif dimana Sig. (2-tailed) $<\alpha(0,000$ $<0,05$ ) (Okmarisa et al., 2016). Penerapan model pembelajaran Problem Based Learning dapat meningkatkan motivasi belajar pada siklus I sebesar $50 \%$ menjadi 64,29\% pada siklus II (Pratiwi et al., 2018). Penggunaan model Problem Based Learning dapat meningkatan hasil belajar kimia dari pretest rata-rata 27,2 menjadi 63,95 dan 72,5 di dua kelas eksperimen I dan eksperimen II, masing-masing. Selain itu, hasil belajar pesrta didik yang diajarkan dengan model Pembelajaran Berbasis Masalah dan pendekatan ilmiah memberikan kartu berpasangan yang lebih tinggi daripada menggunakan buku teks sebagai media (Silaban et al., 2020). Hasil penelitian ini merupakan analisis faktor awal pengembangan keterampilan generik dalam kursus yang diselenggarakan sesuai dengan prinsip Problem Based Learning menunjukkan empat kelompok keterampilan generik yang berbeda yang dikembangkan: keterampilan interaksi, keterampilan pribadi, keterampilan pemecahan masalah dan kreativitas dan keterampilan pengetahuan. Karena itu, hasil berkontribusi pada topik aktual untuk meningkatkan kemampuan kerja lulusan melalui penilaian generik keterampilan dalam pendidikan tinggi (Mekovec et al., 2018).

\section{Discovery Learning}

Penerapan model Discovery Learning pada materi larutan penyangga dapat meningkatkan prestasi belajar (aspek kognitif $63 \%$ pada siklus I meningkat menjadi $81 \%$ pada siklus II) (Istiana et al., 2015). Model Discovery Learning juga efektif dalam meningkatkan keterampilan berpikir lancar dengan perolehan perhitungan uji perbedaan dua rata-rata $n$-Gain siswa diperoleh nilai

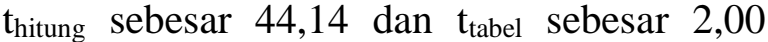
(Murdiandari et al., 2015). Ada perbedaan dalam hasil pembelajaran kimia antara siswa yang diajar dengan belajar model Dicscovery Learning menggunakan virtual lab, real lab atau media animasi komputer $(\mathrm{F}=8,634$ dan sig $=0,000)$. Hasil belajar siswa dari penemuan model pembelajaran dengan media lab virtual $(88,33)$ lebih tinggi daripada hasil belajar siswa dengan media real lab $(86,0)$ dan dengan media animasi komputer $(78,16)$ (Panggabean et al., 2017).

\section{Macromedia Flash}

Penggunaan macromedia flash dapat meningkatkan hasil belajar pada kelas eksperimen dengan nilai rata-rata dari 40,46 menjadi 62,34 (Sinaga \& Harahap, 2015). 
Hasil penelitian menunjukan bahwa pembelajaran peer tutoring dilengkapi animasi macromedia flash dapat meningkatkan: (1) motivasi berprestasi siswa pada materi kelarutan dan hasil kali kelarutan, pada siklus I diperoleh persentase pencapain motivasi berprestasi siswa sebesar $67 \%$ meningkat menjadi $92 \%$ pada siklus II; (2) prestasi belajar dalam aspek kognitif maupun afektif siswa pada materi kelarutan dan hasil kali kelarutan. Pada siklus I ketuntasan belajar siswa 58\%, sedangkan pada siklus II mencapai $83 \%$. Untuk aspek afektif pada siklus I persentase pencapaiannya sebesar $71 \%$ dan meningkat menjadi $100 \%$ pada siklus II (Mawarni et al., 2014). Hasil dari penelitian ini menunjukkan bahwa: (1) penerapan model pembelajaran RTE dilengkapi macro media flash dapat meningkatkan kemampuan memori siswa pada materi sistem periodik unsur. Hal ini dapat dilihat dari kemampuan memori siswa pada siklus I dan siklus II. Persentase kemampuan memori siswa pada siklus I $46,88 \%$ dan $65,63 \%$ pada siklus II; (2) Penerapan model pembelajaran RTE dilengkapi macromedia flash dapat meningkatkan prestasi belajar siswa pada materi sistem periodik unsur. Pada siklus I, persentase ketuntasan belajar siswa sebesar $37,5 \%$ dan pada siklus II persentase ketuntasan belajar siswa meningkat $87,5 \%$. Pada aspek afektif, menunjukkan bahwa terdapat peningkatan persentase dari $62,5 \%$ pada siklus I dan $65,5 \%$ pada siklus II (Mulatsari et al., 2016). Hasil penelitian menunjukkan bahwa terdapat pengaruh model pembelajaran STAD dengan menggunakan media animasi macromedia flash player dan molymod terhadap prestasi belajar siswa pada materi pokok Ikatan Kovalen yaitu prestasi kognitif dan afektif siswa pada pembelajaran STAD dengan media animasi macromedia flash player lebih baik daripada molymod (Sari et al., 2013).

\section{METODE}

Penelitian ini telah dilakukan di SMA Negeri 10 Medan Jalan Tilak No. 108 Medan. Populasi penelitian ini adalah seluruh siswa kelas XI SMA Negeri 10 Medan sebanyak 3 kelas. Dalam penelitian ini sampelnya diambil secara random dari populasi yang homogen sebanyak dua kelas yaitu kelas XI IPA 2 terdiri 34 siswa dan XI IPA 3 terdiri 34 siswa jadi total sampel berjumlah 68 siswa.

Desain penelitian ini adalah "OneGroup pretest-posttest Design", yaitu desain penelitian yang terdapat pretest sebelum diberi perlakuan dan posttest setelah diberi perlakuan. Dengan demikian dapat diketahui lebih akurat, karena dapat membandingkan dengan diadakan sebelum diberi perlakuan.

Tabel 1. One-Group pretest-posttest Design

\begin{tabular}{|c|c|c|c|}
\hline Kelompok & Pretest & Perlak & osttest \\
\hline A (Eksperimen 1) & $\mathrm{T}_{1}$ & $\mathrm{X}_{1}$ & $\mathrm{~T}_{2}$ \\
\hline B (Eksperimen 2) & $\mathrm{T}_{1}$ & $X_{2}$ & $\mathrm{~T}_{2}$ \\
\hline
\end{tabular}

Keterangan:

$\mathrm{T}_{1}$ : Tes hasil belajar sebelum diberikan perlakuan

$\mathrm{T}_{2}$ : Tes hasil belajar sesudah diberikan perlakuan

$\mathrm{X}_{1}$ : Kelas yang dibelajarkan dengan model PBL menggunakan macromedia flash

$\mathrm{X}_{2}$ : Kelas yang dibelajarkan dengan model DL menggunakan macromedia flash

\section{HASIL DAN PEMBAHASAN}

Pengujian Hipotesis pertama diuji dengan menggunakan uji One sample t-test dan menggunakan program SPSS Versi 20. Hasil pengujian hipotesis pertama untuk data hasil belajar kelas eksperimen 1 dan kelas eksperimen 2 dapat dilihat pada tabel di bawah ini.

Tabel 2. Analisis Data Hipotesis Pertama

\begin{tabular}{cccccc}
\hline \multirow{2}{*}{ Data } & \multicolumn{2}{c}{ Data Kelas } & $\mathrm{t}_{\text {hitung }}$ & $\mathrm{t}_{\text {tabel }}$ & Ket \\
& Eks 1 & Eks 2 & & & \\
\hline \multirow{3}{*}{ Manual } & $\bar{x}=80,47$ & $\bar{x}=75,31$ & $\mathrm{t}_{1=7,081}$ & & \\
& $\mathrm{~S}=8,363$ & $\mathrm{~S}=8,975$ & $\mathrm{t}_{2=3,349}$ & & Ha \\
& & & & & diteri \\
SPSS & $\bar{x}=80,47$ & $\bar{x}=75,31$ & $\mathrm{t}_{1=7,081}$ & 0.000 & ma \\
20 & $\mathrm{~S}=8,363$ & $\mathrm{~S}=8,975$ & $\mathrm{t}_{2=3,349}$ & 0.002 & \\
\hline
\end{tabular}


Pengujian Hipotesis kedua diuji dengan menggunakan uji Anava dua jalur dan menggunakan program SPSS Versi 20 yaitu General Linear Model-Univariate. Hasil pengujian hipotesis kedua untuk data motivasi belajar dan hasil belajar pada kelas eksperimen 1 dan kelas eksperimen 2 dapat dilihat pada tabel di bawah ini.

Tabel 3. Analisis Data Hipotesis Kedua

\begin{tabular}{|c|c|c|c|c|c|}
\hline No & Data & $\begin{array}{c}\text { Sumber } \\
\text { Variasi }\end{array}$ & $\mathrm{F}_{\text {hit }}$ & $\begin{array}{c}\mathrm{F}_{\text {tabel }} / \\
\text { Sig }\end{array}$ & Kes \\
\hline \multirow{3}{*}{1} & \multirow{3}{*}{ Manual } & Faktor A & 6,007 & 4,00 & Nyata \\
\hline & & Faktor B & 0,02 & 4,00 & Tidak Nyata \\
\hline & & Interaksi $\mathrm{AB}$ & 3,917 & 3,45 & Nyata \\
\hline \multirow{3}{*}{2} & \multirow{3}{*}{ SPSS } & Faktor A & 6.235 & 0.015 & Nyata \\
\hline & & Faktor B & 0.025 & 0.975 & Tidak Nyata \\
\hline & & Interaksi $\mathrm{AB}$ & 3.860 & 0.027 & Nyata \\
\hline
\end{tabular}

Pada kolom data Manual dan SPSS diperoleh uji $t$ secara manual dan SPSS hampir sama dan menyatakan bahwa pengujian secara manual dengan spss berbanding lurus dengan nilai sig. 0.015 ; $0.975 ; 0.027$. Karena nilai sig. $<0,05$ maka $\mathrm{H}_{\mathrm{a}}$ diterima atau $\mathrm{H}_{\mathrm{o}}$ ditolak yang berarti hipotesis ketiga diterima dan teruji kebenarannya pada taraf $\alpha=0,05$ sehingga dapat disimpulkan bahwa terdapat interaksi antara kelas dan motivasi belajar siswa terhadap hasil belajar siswa.

Gambar 1. Uji Anava dengan SPSS

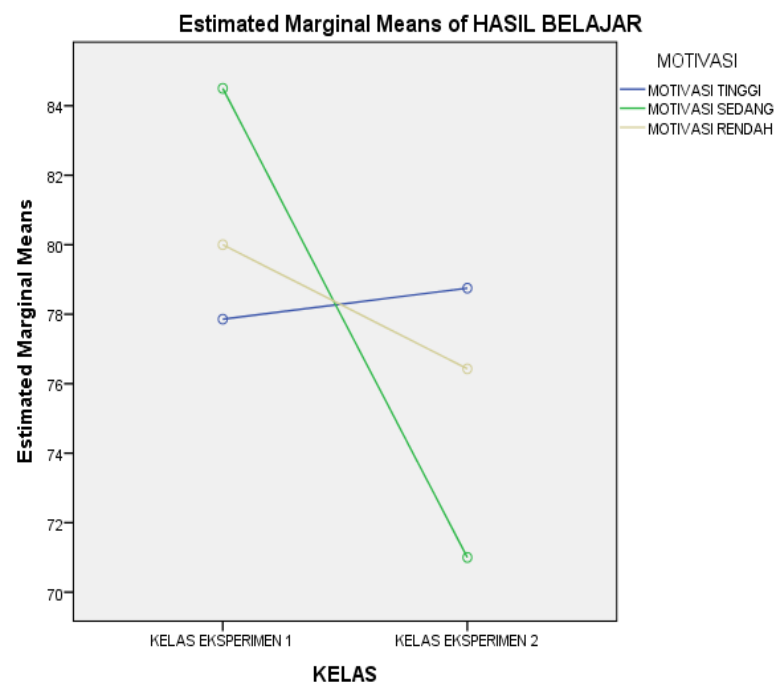

Dari hasil penelitian diperoleh bahwa: (1) Terdapat perbedaan nilai rata-rata hasil belajar siswa yang diajarkan dengan menerapkan model Problem Based Learning sebesar 80,47 menggunakan macromedia flash dimana diperoleh uji t sebesar 7,187 dan nilai rata-rata hasil belajar siswa yang diajarkan dengan menerapkan model Discovery Learning menggunakan macromedia flash dimana diperoleh uji $\mathrm{t}$ sebesar 3,347. Dimana tabel sebesar 1,684 sehingga $t_{\text {hitung }}>t_{\text {tabel }}$ yang menandakan bahwa nilai rata-rata hasil belajar siswa yang dibelajarkan dengan model PBL dan DL lebih besar daripada nilai KKM. Didukung penelitian sebelumnya yang menyatakan bahwa pembelajaran Problem Based Learning (PBL) dilengkapi macromedia flash dapat meningkatkan kemampuan berpikir kritis dan prestasi belajar siswa pada siklus I sebesar $54,05 \%$ meningkat menjadi $78,38 \%$ pada siklus II (Nuryanto et al., 2015).

(2) Terdapat interaksi antara kelas dan motivasi belajar siswa terhadap hasil belajar siswa. Analisis interaksi diperoleh hasil faktor (A) memiliki harga $F_{\text {hit }}$ sebesar $6,007>\mathrm{F}_{\text {tabel }} 4,00$ berarti faktor A nyata; hasil antar baris (B) memiliki harga $F_{\text {hit }}$ sebesar $0,02<\mathrm{F}_{\text {tabel }} 4,00$ berarti faktor $\mathrm{B}$ tidak nyata; hasil interaksi $(\mathrm{AB})$ memiliki harga $F_{\text {hit }}$ sebesar 3,917> $F_{\text {tabel }}$ 3,45 berarti faktor $\mathrm{AB}$ nyata. Hasil ini membuktikan bahwa faktor $\mathrm{A}$ atau kombinasi faktor $\mathrm{A}$ dan B dapat diterapkan menggunakan model Problem Based Learning dan Discovery Learning dengan macromedia flash. Hal ini menandakan bahwa terdapat interaksi kelas dan motivasi terhadap nilai hasil belajar siswa. Didukung penelitian sebelumnya yang menyatakan bahwa penerapan problem based learning dapat meningkatkan motivasi belajar pada kelas kontrol sebesar 72,48 dan pada kelas eksperimen sebesar 77,57 (Sudirman et al., 2017).

\section{DISKUSI}

Pada penelitian ini ditemukan bahwa: (1) terdapat perbedaan nilai ratarata hasil belajar siswa yang diajarkan dengan menerapkan model Problem Based Learning sebesar 80,47 menggunakan macromedia flash dimana diperoleh uji $\mathrm{t}$ sebesar 7,187 dan nilai rata-rata hasil belajar siswa yang diajarkan dengan menerapkan model Discovery Learning 
menggunakan macromedia flash dimana diperoleh uji t sebesar 3,349. Dimana $t_{\text {tabel }}$ sebesar 1,684 sehingga $t_{\text {hitung }}>t_{\text {tabel }}$ yang menandakan bahwa nilai rata-rata hasil belajar siswa yang dibelajarkan dengan model Problem Based Learning dan Discovery Learning lebih besar daripada nilai KKM; (2) terdapat interaksi antara kelas dan motivasi belajar siswa terhadap hasil belajar siswa. Analisis interaksi diperoleh hasil faktor (A) memiliki harga $F_{\text {hit }}$ sebesar 6,007 $>F_{\text {tabel }}$ 4,00 berarti faktor A nyata; hasil antar baris (B) memiliki harga $F_{\text {hit }}$ sebesar $0,02<F_{\text {tabel }} 4,00$ berarti faktor $B$ tidak nyata; hasil interaksi (AB) memiliki harga $F_{\text {hit }}$ sebesar 3,917> $F_{\text {tabel }}$ 3,45 berarti faktor $\mathrm{AB}$ nyata. Faktor A merupakan Kelas Eksperimen 1 yang dibelajarkan dengan model Problem Based Learning menggunakan macromedia flash dan Kelas Eksperimen 2 yang dibelajarkan dengan model Discovery Learning menggunakan macromedia flash. Faktor B merupakan motivasi belajar siswa yang dibagi menjadi motivasi tinggi, sedang dan rendah.

\section{KESIMPULAN}

Berdasarkan uraian di atas, dapat ditarik kesimpulan bahwa: (1) Penerapan model pembelajaran yang inovatif dan penyusunan media yang sesuai dengan sintaks model pembelajaran tersebut sangat tepat dipakai untuk mengajarkan materi termokimia di SMA; (2) Penerapan faktor A atau mengkombinasikan faktor A dan B sangat tepat untuk meningkatkan hasil belajar siswa pada materi termokimia.

\section{DAFTAR PUSTAKA}

Desriyanti, R., \& Lazulva. (2016). Penerapan Problem Based Learning Pada Pembelajaran Konsep Hidrolisi Garam Untuk Meningkatkan Hasil Belajar Siswa. Jurnal Tadris Kimiya, 1(2), 7078.

https://doi.org/10.15575/jta.v1i2.1247

Istiana, G. A., Nugroho, A., \& Catur, S. (2015). Penerapan Model Pembelajaran Discovery Learning
Meningkatkan Aktivitas Dan Penyangga Pada Siswa Kelas XI IPA Semester II SMA Negeri 1 Ngemplak Tahun Pelajaran 2013 / 2014. Jurnal Pendidikan Kimia (JPK), 4(2), 65-73.

Mawarni, E., Mulyani, B., \& Yamtinah, S. (2014). Penerapan Peer Tutoring Dilengkapi Animasi Macromedia Flash Dan Handout Untuk Meningkatkan Motivasi Berprestasi Dan Prestasi Belajar Siswa Kelas XI IPA 4 SMAN 6 Surakarta Tahun Pelajaran 2013/2014 Pada Materi Kelarutan Dan Hasil Kali Kelarutan. Jurnal Pendidikan Kimia Universitas Sebelas Maret, 4(1), 29-37.

Mekovec, R., Anicic, K. P., \& Arbanas, K. (2018). Developing undergraduate it students' generic competencies through problem-based learning. TEM Journal, $7(1)$, 193-200. https://doi.org/10.18421/TEM71-24

Mulatsari, D., VH, E., \& Mulyani, B. (2016). Penerapan Model Pembelajaran Rotating Trio Exchange (RTE) Menggunakan Macromedia Flash Untuk Meningkatkan Kemampuan Memori Dan Prestasi Belajar Kimia Pada Materi Sistem Periodik Unsur X SMK Muhammadiyah 2 Sragen Tahun Pelajaran 2013/2014. Jurnal Pendidikan Kimia Universitas Sebelas Maret, 5(3), 54-58.

Murdiandari, W., Fadiawati, N., \& Tania, L. (2015). Pembelajaran Model Discovery Learning Untuk Meningkatkan Keterampilan Berpikir Lancar Pada Materi Laju Reaksi. Jurnal Pendidikan Dan Pembelajaran Kimia, 4(2), 581592.

Nuryanto, N., Utami, B., \& Saputro, A. (2015). Penerapan Model Pembelajaran Problem Based Learning (PBL) Dilengkapi Macromedia Flash Untuk Meningkatkan Kemampuan Berpikir Kritis Dan Prestasi Belajar Siswa Pada Materi Pokok Termokimia Kelas XI Siswa SMA Negeri 2 Karanganyar T.P 2014/2015. Jurnal Pendidikan Kimia, 
4(4), 87-94.

Okmarisa, H., Darmana, A., \& Suyanti, D. (2016). Implementasi Bahan Ajar Kimia Terintegrasi Nilai Spiritual Dengan Model Pembelajaran Problem Based Learning ( PBL ) Berorientasi Kolaboratif Untuk Meningkatkan Hasil Belajar Siswa. Jurnal Pendidikan Kimia, $\quad 8(2), \quad 130-135$. https://doi.org/10.24114/jpkim.v8i2.443 9.

Panggabean, F. T. M., Silaban, R., \& Hutabarat, W. (2017). Application of Discovery Learning Model Using Virtual Lab , Real Lab , and Computer Animations to Increase Student Learning Result Reviewed From The Ability of Critical Thinking Students. Proceedings The 2nd Annual International Seminar on Transformative Education and Educational Leadership (The 2nd AISTEEL) EISSN: 2548-4613, October, 455-457.

http://aisteel2017.unimed.ac.id/wpcontent/uploads/2018/03/455-457.pdf.

Permendikbud. (2014). Permendikbud nomor 104 tahun 2014 Tentang Penilaian Hasil Belajar oleh Pendidik pada Pendidikan Dasar dan Pendidikan Menengah. In Kementrian Pendidikan dan Kebudayaan RI.

Pratiwi, B. L., Kuswardi, Y., \& Fitriana, L. (2018). Upaya Peningkatan Motivasi Belajar Siswa Melalui Model Pembelajaran Problem Based Learning Dengan Strategi Motivasi ARCS (Attention, Relevance, Confidence, Satisfaction) Pada Siswa Kelas XI IPA 2 SMA Negeri 1 Petanahan Tahun Pelajaran 2017/2018 Bibit. Jurnal Pendidikan Matematika Dan Matematika (JPMM) Solusi, 2(2), 161169.

Sari, A. P., Ashadi, \& Nugroho, C. S. A. (2013). Studi Komparasi Model Pembelajaran Stad Dengan Menggunakan Media Animasi
Macromedia Flash Player Dan Molymod Pada Pembelajaran Kimia Materi Pokok Ikatan Kovalen Ditinjau Dari Kreativitas Siswa Kelas X SMAN 2 Sukoharjo Tahun Pelajaran 2011/2012. Jurnal Pendidikan Kimia Universitas Sebelas Maret, 2(2), 110116.

Silaban, R., Panggabean, F. T. M., Hutapea, F. ., Hutahaean, E., \& Alexander, I. . (2020). Implementasi Problem BasedLearning (PBL) Dan Pendekatan Ilmiah Menggunakan Media Kartu Untuk Meningkatkan Hasil Belajar Peserta Didik Tentang Mengajar Ikatan Kimia. Jurnal Ilmu Pendidikan Indonesia, 8(2), 69-76.

https://doi.org/10.31957/jipi.v8i2.1234.

Sinaga, K., \& Harahap, M. B. (2015). Pengaruh Model Pembelajaran Inquiry Training Menggunakan Macromedia Flash Terhadap Hasil Belajar Siswa Pada Materi Pokok Pengukuran Di Kelas X IPA Semester I MAN Lubuk Pakam T.P 2014 / 2015. Inovasi Pembelajaran Fisika (INPAVI), 3(3). https://doi.org/10.24114/inpafi.v3i3.537 9.

Sudirman, R., Nursalam, \& L, M. S. (2017). Penerapan Model Problem Based Learning Berbasis Children Learning In Science Terhadap Motivasi Dan Hasil Belajar. Jurnal Pendidikan Fisika, 5(1), 49-55. http://journal.ulnalauddin.ac.id/indeks.php/PendidikanFis ika.

Sutiani, A., Zainuddin, Darmana, A., \& Panggabean, F. T. M. (2020). The Development of Teaching Material Based on Science Literacy In Thermochemical Topic The Development of Teaching Material Based on Science Literacy In Thermochemical Topic. Journal of Physics: Conference Series, 1462, 012051. https://doi.org/10.1088/17426596/1462/1/012051. 